\title{
Women's Tenure Rights and Land Reform in Angola
}

\author{
ALLAN CAIN \\ Development Workshop Angola \\ allan.devworks@angonet.org \\ Paper prepared for presentation at the \\ "2019 WORLD BANK CONFERENCE ON LAND AND POVERTY" \\ The World Bank - Washington DC, \\ March 25-29, 2019
}

Copyright 2019 by author. All rights reserved. Readers may make verbatim copies of this document for noncommercial purposes by any means, provided that this copyright notice appears on all such copies. 


\title{
Women's Tenure Rights and Land Reform in Angola
}

\begin{abstract}
:
Current Angolan municipalisation reforms present a unique opportunity to affect local practice on how community and individual land-holder tenure is administered and to protect women's equitable rights to land. Angola is a post-war country, with weak land tenure legislation and limited local government management capacity. Customary traditions are practiced in the various regions a of the country do not respect women's rights of ownership and inheritance. More than 62 percent of the population live in informal settlements with insecure land tenure under the threat of forced evictions. Families living in poor communities affected by the expansion of cities and towns are particularly vulnerable. Of these, families lead by women are the most at risk. Securing rights to land and housing assets are important to livelihoods of women headed households by permitting access to financing that they require to grow their enterprises as well as for incrementally upgrading their housing.
\end{abstract}

\section{Keywords:}

Women, gender, tenure, land reform, customary, human rights

\section{Author:}

Allan Cain O.C. is the founding director of Development Workshop and has been a Visiting Professor at the School for International Development and Global Studies at the University of Ottawa. He is an architect, specialist in project management, participatory planning, sustainable urban development and water \& sanitation. He has lived and worked in Africa for the last 35 years. He has a degree in Environmental Studies, did his professional studies at the Architectural Association (London, UK) and further specialist studies at Harvard University and Bolder, Colorado. Mr. Cain was awarded an Order of Canada in 2004 for his work in international development, social housing and contribution to peacebuilding in Angola. He has worked as a consultant and lead research projects for the World Bank, UN Habitat the European Union and other international organisations. He is the DW project leader on the International Development Research Centre supported programme on Climate Change, Flooding and Water-Supply in Angola's Coastal Cities. He has lectured at universities in Canada, China, Angola, Norway, USA, South Africa and UK. He is a member of the advisory board for Environment \& Urbanism Journal of the International Institute for Environment \& Development (IIED) and on the boards of several other development institutions. His articles and papers have been published widely in international journals. 


\section{Women's Tenure Rights and Land Reform in Angola}

\section{Statutory vs Customary Land Rights}

Angola is a post-war country, with weak land tenure legislation and limited local government management capacity. More than 62 percent of the population live in urban and peri-urban areas and are increasing and putting pressure on land and services. Much of the population in these areas lives in informal settlements with insecure land tenure under the threat of forced evictions. Land conflict is an issue affecting urban, rural and peri-urban areas. Poor communities affected by the expansion of cities and towns are particularly vulnerable. Of these, women are the most vulnerable. Access to land is a matter of survival, for those who's only income and accumulated assets are drawn from their land. More than half of families depend on informal sector activities to sustain themselves. Securing rights to land and housing assets are important to livelihoods of women headed households by permitting access to financing that they require to grow their enterprises as well as for incrementally upgrading their housing.

The post-socialist inheritance has left the State as the formal owner of all land. In practice however there is an active informal land market, large scale-land grabs by urban elites, and increasing conflicts affecting communities, small holders and families, particularly those headed by women. While the existing land law recognizes customary land use (residential, traditional agriculture and access to water) customary traditions are practiced in the various regions and cultures of the country, women's rights of ownership and inheritance are weakly protected and are often unrecognised.

The formal statutory systems governing land rights and transactions in Angola are more favourable to women than in many African countries, but they are not yet fully realized and implemented in practice. As it emerged from almost 30 years of civil war, Angola enacted legislation that articulates principles of nondiscrimination and gender equity. A progressive family law proactively provides for the rights of women in common law marriages and the inheritance rights of daughters. However, despite the mandates of the formal law, customary laws and traditional practices prevail. Those customary laws and practices mostly favour men, and men dominate Angola's political, economic, and social spheres. the majority of Angolan women remain trapped with a lack of assets, illiteracy, limited economic opportunities, and the need to care for children and relatives. Land rights provide a critical asset to all women regardless of their circumstances but most particularly those with the fewest options. The Government of Angola's current land and decentralization reforms provide an opportunity to design a strategy for protecting and improving women's rights to land and livelihoods potential. 
Despite constitutional provisions, all citizens are not equal in practice before the law, due to inadequate information, limited resources, and weak local administrative systems. Traditional authorities, such as local chiefs (sobas) are often the only administrators, mediators, and adjudicators of land rights that women will ever encounter. Less than one percent of the traditional chiefs are women. These individuals and local institutions of governance and dispute resolution generally apply customary law and local practice to guide decisions regarding land rights. Under traditional succession practices, Angolan women generally do not have land access equal to men's, as family land passes to sons and male relatives of the deceased husband. Women generally move to her husband's house upon marriage and often live on and cultivate land owned by the husband's family or granted by the family or soba (traditional authority) to the husband. If the women are subsequently widowed, abandoned, or divorced, the former husband or relatives of the husband may force the women from the husband's land and home.

The inheritance practices upon which customary law in Angola are based are often discriminatory towards women. However, women are responsible for generating income, from informal trading or cultivation providing for household food security, and raising children and caring for the ill and elderly. The proportion of women heads of household continues to grow. $34.5 \%$ of households and $46 \%$ of per-urban slum households are headed by women ${ }^{1}$. They also form the majority of those families living in extreme poverty. The problem of poverty within communities is also a result of inability to develop alternative ways to generate income. More than half of families depend on informal sector activities to sustain themselves. Assisting women to explore alternative and improved income generating opportunities that may contribute diversify their income sources, providing them with knowledge to access financial services, as well as facilitating their access to loans for investing in their small businesses, will contribute to improve their abilities to increase their possibilities to reach economical independence for themselves and for their families. Land tenure security is important for securing credit for poor families and women-headed households.

In the central plateau of Angola, the implementation of national policies respecting women's rights remains incomplete (specifically for small holdings and peri-urban occupations). The practice of the existing customary system are still widely observed specifically, territories are administered under the leadership of traditional leaders, the "Sobas" (at Ombala level, a kind of a traditional district) and of the "Seculos" (at community level).

\footnotetext{
${ }^{1}$ World Bank (2016) https://data.worldbank.org/indicator/SP.HOU.FEMA.ZS, and Henda Ducados, "Luanda Peri-Urban Gender \& Household Profile" http://www.dw.angonet.org/content/luanda-peri-urban-household-gender-profile2001-2002.
} 
Past land reform programmes, together with the break-up of communal land holdings, have led to the transfer of exclusive land rights to males as heads of households. This ignores both the existence of female-headed households and the rights of married women to a joint share. However women, living in the customary law system, are often unaware of their statutory rights. Poor access to information also contributes to the lack of knowledge by citizens of their rights. By providing adequate and better information to women about their rights and access to land, as well as providing knowledge on land rights to the communities where they are included, will result in an increased awareness among women of their right to equally access and control land and housing.

\section{Land Conflicts}

Angola's four decades of armed conflict were characterized by land expropriation, forced removals, resettlement, and the massive internal displacement of rural and urban populations. Prior to independence Portuguese colonial settlers had appropriated over $40 \%$ of registered land and denied African occupation of much of the remaining forested and reserve land. During the civil war after independence in 1975, warring parties used forced removals of populations from their lands as tools of war (Cain 2012 p.173). Since the end of the war in 2002, the reintegration of politically divided populations and ex-combatants-was linked to access to land that became a primary factor in social reconstruction. However post-war land legislation did not provide the opportunity for Angolan peasants and communities to register their properties or gain restitution for their lands that had been expropriated during the colonial settlers' landgrab. The government distributed the equivalent of 50 percent of the land held by commercial farmers in colonial times to a small number of mainly urban-based absentee owners, who paid insignificant prices for secure tenure rights in order to eventually exploit these lands commercially. As happened in colonial times, the modern commercial sector was allocated an excess of underused land, which was set aside by the new owners for possible future use or speculation. Local peasant farmers, on the other hand, were treated by the Angolan state much like they had been treated under the colonial regime (Pacheco 2002). They were left with small, often scattered parcels of land divided between tiny irrigated garden plots and less fertile, seasonally used lavras (plowed plots) for staple crops. Postwar legislation made no provision for existing or previous possession or occupants' rights (usucapiao) by which property rights may be acquired through continued use over time. Therefore the main driving force for the rapid return of rural IDPs to their areas of origin was their need to reclaim family lands and the fear of finding it staked out by an intruder or usurper often holding title deeds issued by a government official. Resettlement of IDPs, excombatants, and returning refugees produced innumerable local conflicts over land allocation, often resulting in clashing interests 
between the returnees and those who had stayed behind in their areas of origin. The role of traditional authority in land management had been eroded through the years of colonial rule and civil war. However, the return and resettlement of almost 3 million people to their rural areas of origin provided a renewed role for traditional leaders in dealing with local land conflicts and providing testimony regarding families' historical land claims.

Disagreements over land became more frequent as the scramble for land between powerful commercial interests and peasants threatened evictions of families who had fled the conflict-ravaged countryside to make homes on land without sufficient legal title. In rural communities, fertile agricultural land with relatively easy access to urban markets was in high demand. These sites frequently became the focus of disputes between residents and returning IDPs as well as more powerful commercial interests.

A recent diagnostic study carried out in Huambo province in Angola's Central Highlands revealed that 75\% of the peasant small holders said that they do not see any benefit from the commercial farms near the communities. Only $1 \%$ of respondents mentioned any benefit from commercial exchanges between the community and the commercial farmers and no-one reported that the proximity of commercial farms brought the community any improvement in access to services like water and electricity. Approximately $10 \%$ of small-holder respondents said that because many farms were acquired through forced expropriation of community lands they felt threatened by the presence of commercial farmers in their neighborhoods and that with the passage of time they feared conflicts which could lead to the further expropriation of local community's lands.

Land conflict is an issue affecting urban, rural and peri-urban areas. In urban areas the poor risked being uprooted from their homes because their sprawling musseques frequently occupied ideal locations for elite housing developments, offices, and roads. Poor communities affected by the expansion of cities and towns are particularly vulnerable. Of these, women, elderly and people living with disabilities are the most vulnerable. Access to land is a matter of survival, for those who's only income and accumulated assets are drawn from their land.

\section{Advocacy and Public Policy Reform}

Angola is currently undertaking major governance reforms to empower municipalities with elected local councils. A key to municipalisation will entail decentralising the management of land. It will be necessary to build the capacity of local administrations and local communities to strengthen family land tenure and 
protect the rights women. If the poor majority are to be the primary beneficiaries of land tenure reform, the design of tools for managing land rights must take this into account. Poorer groups will have more effective access to such procedures where they receive clear information about how the system is meant to operate, and where the local government institutions responsible are located close by, working in local languages using tools of mapping and recording, including accepting oral testimonies as evidence to support claims. Effective and responsive judicial and land administration systems which are accessible to poor people and vulnerable groups are therefore crucial components of successful, pro-poor land policy reform. Development Workshop is working at the public policy level with the Government's National Land Commission developing a land policy reform that aims to address contradictions between formal, informal and customary tenure, which have lead to conflicts and inefficiencies. Women status in traditional rules is one area of contradiction that needs to be addressed.

Women have a lower level of knowledge about their land rights compared to men with the exception of the 15-17 age group. The recent study in Huambo province (Development Workshop 2018) revealed that of the men interviewed aged 18-25, 20\% said they were aware of the existence of the land law, and only $15 \%$ of women respondents claimed to have knowledge about the law. The percentage difference between men and women over the age of 36 was $20 \%$ (see Figure 1 ).

Current Angolan municipalisation reforms present a unique opportunity to affect local practice on how community and individual land-holder tenure is administered and protected. The Ministry for Territorial Administration and the Ministry of Planning and Housing is developing a set of land-management and mapping tools for the use by local municipal administrations. The tools employ the principal of "social domain tenure" (STDM) ${ }^{2}$ promoted by the UN's Global Land Tools Network GLTN, Participatory Inclusive Land Readjustment (PILaR) and rapid gender tenure assessments.

The protection of gender rights should be rolled out in the new municipal government reforms to be implemented across Angola. These reforms involve the election of municipal councils Autarquias. The raising of public awareness about the rights of women to equal access to assets such as land, housing and means of livelihoods will ensure that these issues are protected at the local government level.

\footnotetext{
${ }^{2}$ Social Tenure Domain Model (STDM) participatory land information tool allows for the recordation of all possible types of tenures; STDM enables to show what can be observed on the ground in terms of tenure as agreed within local communities. Participatory mapping of boundary surveys based on handheld GPS observations, or by drawing boundaries on satellite images are some of the STDM tools developed in Angola. Information on customary tenure and informal settlement tenure are captured and registered through STDM.
} 
Advocacy work is required by civil society organizations to combat gender inequality, to promote the status of women with a focus on cultural change particularly in communities where customary land traditions are still strong. Raising the awareness on the existing legal framework and rights of access to the land, housing and livelihoods, particularly for women, is a way to provide them with the tools to protect themselves against unfavourable rules set by customary practice and against land-grabs by urban elites. Women are too often discriminated against in terms of access and land tenure, although they are the ones who are mostly linked to the tasks of cultivating the land. Land conflicts are most often mediated by traditional leaders (see Figure 2) rather than government authorities who are more knowledgeable about legal rights. The encroachment by commercial real-estate developers and expropriation for plantation farming and mono-cropping limit further their access to land. Providing them with the information on their statutory land rights can contribute to safeguarding their tenure.

A participative framework for planning the use of land needs to be promoted, with the purpose to accommodate the diverse interests of different groups using the land, thereby preventing potential conflicts. Small-holder and family agricultural production still ensures food security for most communities and in the country as a whole. The political buy-in of municipal authorities and the involvement of local community organizations and farmers associations, will be key. By raising the general awareness about the civic rights of women in the community, and the importance of protecting them for general development the local decision makers need to be influenced to embrace more inclusive customary rules, free of gender discriminatory principles.

Angola is undertaking a major devolution of power and decision-making to municipalities ${ }^{3}$. Civil society has advocated for strong participatory governance reforms. The adoption of participatory gender-sensitive land management tools can have a strong platform for implementation. The capacity of the structures in charge of implementing legislation, land management and arbitration of conflicts needs to be reinforced. Land use planning is currently an activity that lacks coordination among the different institutions at national, provincial, and local level, without clear limits of intervention among them. There is also limitation in terms of skilled human resources capable to provide technically adequate rules for this activity. As a result land grabbing and occupation from powerful groups result often in misappropriation of community land, affecting vulnerable people, among them women. The new elected municipal councils will be required to deal with conflicts resulting from land use and property and find consensual solutions.

\footnotetext{
${ }^{3}$ Angola's first Municipal elections will be held in 2022. 


\section{Co-production with communities and local government}

Co-production of knowledge on land tenure involving participation of communities and local government will require collaboration between municipal administrations and local community associations who are being trained in the use of participatory mapping tools (STDM). Data collected and the land tenure mapping produced is co-owned by the Municipalities and the community associations who engage in its production. The participatory diagnosis will be carried out after the training of local administrations and civil society. "Data ownership" means: the authority to allow or deny access to the data, and the responsibility for the data's accuracy, integrity, and timeliness. The "cadastre" produced provides evidence of legitimate and verifiable land occupation that significantly improves legal tenure.

Women often lack knowledge of their legal rights, including their land rights, marital property rights, and inheritance rights. Similarly local authorities often do not have clear knowledge of statutory rights and may have a weak understanding of the situation related to land issues in their areas of jurisdiction. There is a general lack knowledge of the land law, regulations, and procedures for implementing the laws, including the formalization of land rights and granting of concessions. The strategy to support women's rights to land should be linked with providing training on the laws impacting land rights (both formal and customary) and do institutional capacity building for the new municipal administrations. It is hoped that women's participation in elected decision-making bodies will support efforts to strengthen women's rights.

Land use planning and management is better addressed when there is the involvement of the different institutions in a concerted manner. Innovative co-participation engaging local government and traditional / customary leaders, the private sector, local associative groups, communities, will result in a participative way to approach and find solutions to the existing problems. Together with seeking experiences and lessons learned and shared at regional level or in other countries, will contribute to increase capacity of local networks to engage in and benefit from global and regional networks and knowledge sharing that supports land opportunities for rural women and men.

\section{Recommendations:}

There is a need for the inclusion of a co-ownership clause into Angolan the Land Law. Co-ownership of land between spouses and/or family members is an important principal of land reform. (South Africa and Tanzania that have enacted legislation requiring land co-ownership by married couples)

Development Workshop's research provides evidence of the proportion of women-headed households in peri-urban areas (over $46 \%$ in slum areas of Luanda). Women's land rights be reinforced and for land 
legislation to be brought into compliance with Angolan law. The equal rights of men and women to assets and resources, as supported by the Constitution of the Republic of Angola and the Family Code of Angola, extend to rights of land access and land tenure security (the Family Code, 1989). Marriage is defined in the Family Code and includes registered unions and de facto unions as set forth in Titles III-IV of the Family Code. Pursuant to the principles contained in the Constitution and Family Code, spouses in a marriage, whether a registered or in a de facto union, are presumed to have equal rights to the land and any buildings that they occupy, and the burden is on the spouse claiming otherwise to provide evidence of the claim. It is therefore necessary to create specific land protection programs for women, without neglecting the sources of facilitated access and recording of women's information. In addition, it is recommended to introduce in all registration and titling processes a requirement to include the wife's or partner's name (conventional or traditional marriage) since the owners, man and woman share the same roof.

There is a need to eliminate sources of legal discrimination against women, ethnic and religious minorities, and other disadvantaged groups in economic matters. This includes de facto, as well as, de jure discrimination; this includes efforts to ensure equal rights for women in key economic areas such as land ownership and inheritance. Where the property rights adversely impacted are held by a married couple, whether in a registered or de facto union, payment of cash compensation shall be made jointly to the wife and husband. If the couple elects in-kind compensation, the title to the property transferred shall be in the names of both spouses.

Recommendations to improve women's land rights in Angola include: implementing legislative and policy reform to remove legal constraints on women's rights to land, promoting public information and awareness on women's constraints and opportunities to land access, ensuring the participation of women in the land rights formalization and adjudication processes, and putting in place monitoring and enforcement systems to ensure that land rights formalization efforts successfully recognize and document women's land rights, as well as enforce those rights.

\section{Conclusions:}

Angola has inherited a varied and complex set of landholding and land use practices, the evolution of which has been influenced by customary and cultural traditions, the colonial past, years of conflict and forced migrations, massive urbanization, and the socioeconomic development of the nation. From colonial times until the recent end of the conflict, Angolan legislators have demonstrated a consistent tendency to contain or circumscribe the land rights of the country's rural and poor peri-urban populations and to direct land 
resources to the hands of a few, while at various times supporting the development of commercial farming and mineral extraction (Clover 2005).

The incorporation of international norms of good practice of civic and gender rights into Angolan legislation can result in real improvements in procedures for managing land and protecting the tenure rights of women and small-holders. The introduction of the concepts of public consultation and participatory planning in the post-war public discourse may have influenced the inclusion of these concepts in the land and planning laws. Public consultation on the 2004 Land Law was the first opportunity to lobby for the application of rightsbased legislation. Angolan civil society advocates for the promotion of land tenure rights for women and the protection of the urban and rural poor against arbitrary and forced removals. Land has become a political issue debated in the parliament and is influencing the platforms of political parties. Opportunities are increasing for civil society and community representatives to employ emerging local spaces such as municipal forums and consultative councils in order to bring the debate on land rights into the public arena. Land issues are likely to be high on the agenda of elected municipal councils when they are instituted after the first local governmental elections in 2020 and the constitution of municipalities with decentralized authority and budgets. 
Figures

Figure 1 Gender bias in knowledge of Land Rights (ref Development Workshop 2018)

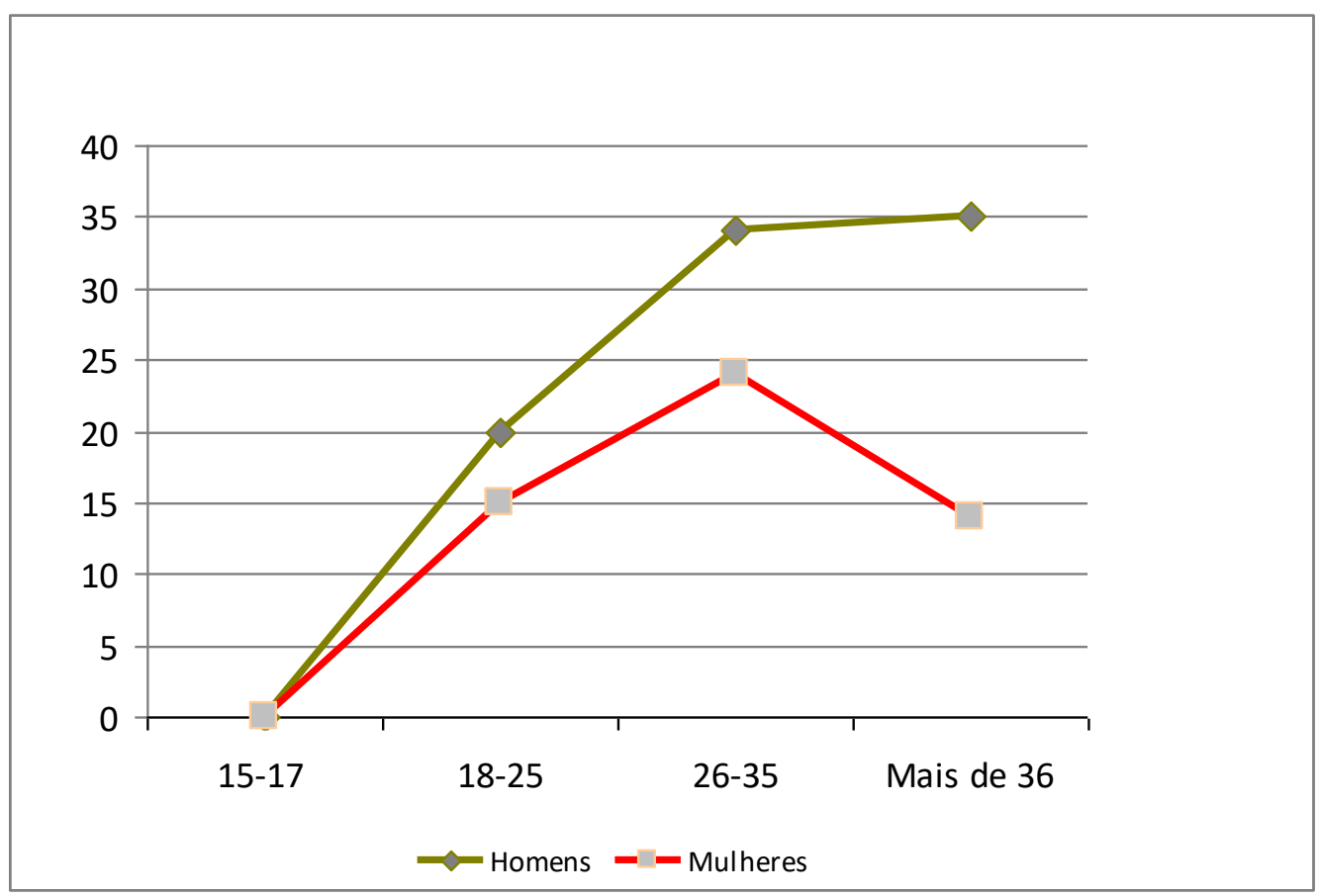

Figure 2 Local actors engaged in mediating conflicts over land (ref Development Workshop 2018)

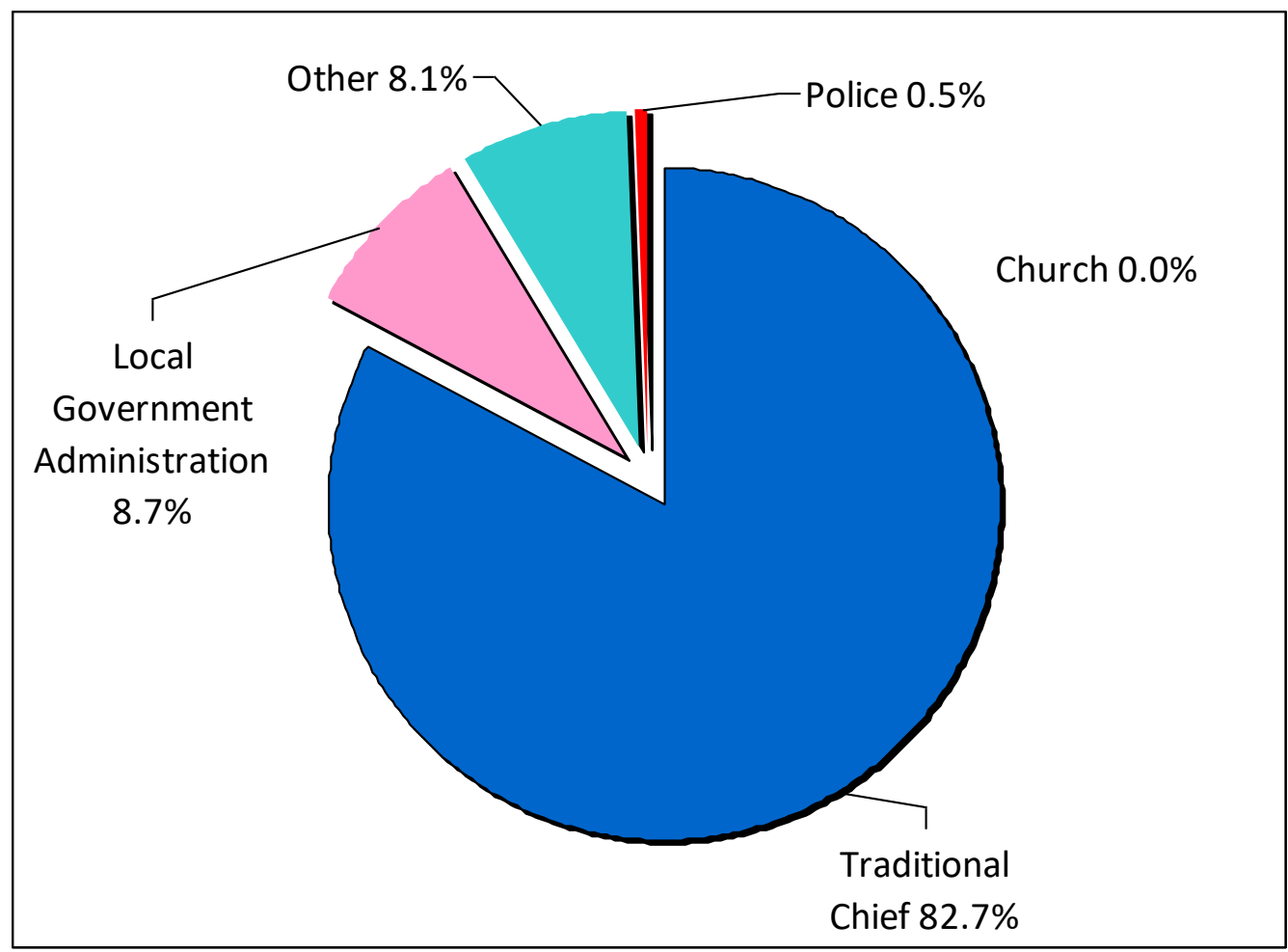




\section{References}

Cain A. (2003) "Land Rights and the Urban Poor", IRIN News, United Nations Office for Humanitarian Affairs.

Cain A. (2004) "Land for the Urban Poor in Post-War Angola Socio-Economic Exclusion - land, credit and basic services" presented to Centre for Urban and Community Studies University of Toronto and Housing Department, City of Toronto Toronto, 24-27 June, 2004.

http://dw.angonet.org/sites/default/files/online lib files/Land\%20for\%20Housing\%20in\%20Angola\%20\%20Toronto\%20Conference\%20-\%20June\%202004.pdf

Cain A. (2007) "Post-Conflict Transformations in Angola's Informal Sector - research \& policy advocacy", presented at Christen Michelsen Institute, 23 November 2007, Bergen, Norway

Cain A. (2008) "Land and Informal Settlement in Post-Conflict Angola", presented to Conference on land, conflict and humanitarian action, Humanitarian Policy Group - Overseas Development Institute (ODI), 07 February 2008, University College London, UK

Cain A. (2010), "Research and practice as advocacy tools to influence Angola's land policies” Environment \& Urbanization Journal, International Institute for Environment and Development (IIED) Vol 22(2): 505522. DOI: 10.1177/0956247810380153 www.sagepublications.

Cain A. (2012), "Participatory \& Inclusive Land Readjustment the case of Huambo, Angola", presented to the Urban Research and Knowledge Symposium - Cities of Tomorrow, $9^{\text {th }}$ October, 2012, World Bank, Barcelona, Spain.

Cain A. (2013), “Luanda’s Post-war Land Markets: Reducing Poverty by Promoting Inclusion” in Urban Forum, March 2013, Volume 24, Issue 1, pp 11-31, Springer, Germany.

http://link.springer.com/article/10.1007/s12132-012-9173-X

Cain A. (2013), “Angola: land resources and conflict", chapter in the Land and Post-Conflict Peacebuilding, in the Series: Post-Conflict Peacebuilding and Natural Resource Management, United Nations Environment Programme (UNEP) and Environmental Law Institute (ELI), January 31st 2013, Routledge, N.Y. http://www.routledge.com/books/details/9781849712316/ 
Cain A., Weber B. \& Festo M., (2013) "Participatory Inclusive Land Readjustment in Huambo, Angola", presented to the World Bank Land Conference, 08 - 11 April 2013 Washington, DC. http://www.dw.angonet.org/sites/default/files/online_lib_files/Cain-336_paper_0.pdf

Cain A. (2016) "Land Markets for Housing in Angola - Policy Paper”, Centre for Affordable Housing Finance in Africa, 22 December 2016, Johannesburg, http://www.housingfinanceafrica.org/wpcontent/uploads/2016/12/Land-markets-for-housing-Policy-paper-2016.pdf

Chianeque L.C. (n.d.) "Women and the Land: The case of the Ovimbundu women of Angola" (unpublished monograph)

Clover, J. (2005) "Land reform in Angola: Establishing the ground rules. In From the ground up: Land rights, conflict and peace in sub-Saharan Africa", ed. C. Huggins and J. Clover. Pretoria, South Africa: Institute for Security Studies.

Development Workshop (2002), “Land Management and Land Tenure in Peri-urban Areas”, Ministry of Urbanism \& Environment, Luanda, United Nations Programme for Human Settlements - HABITAT, Nairobi.

Development Workshop (2004) "Land \& Reintegration of Ex-combatants in Huambo Province in PostWar Angola” Research Report Presented to: World Bank Angola Demobilization and Reintegration Project, and Foreign Affairs Canada - Human Security Programme.

http://dw.angonet.org/sites/default/files/online lib files/Land\%20\%26\%20Demob\%20Final\%20Re port $\% 20-\% 20 H u a m b o \% 202004$.pdf

Development Workshop \& CEHS (2005) “ TERRA - Urban land reform in post-war Angola: research, advocacy \& policy development” (co-editor) Development Workshop Occasional paper No.5, Luanda, Angola. http://www.dw.angonet.org/sites/default/files/pdf/Terra_English.pdf

Development Workshop \& ARD (2008) “Land Rights Formalisation in Rural \& Peri-Urban Settings in Angola" USAID Operations Manual. http://www.dw.angonet.org/forumitem/land-righths-formalizathion$\underline{\text { rural-and-peri-urban-seththings-angola }}$ 
Development Workshop (2011a) The Case of Angola: Strengthening citizenship through upgrading informal settlements, cross country initiative (TF0901110) Technical Assistance in Urban Land Policies. Washington DC: World Bank.

Development Workshop (2011b) Poverty and Environmental Vulnerability in Angola's Growing Slums, Climate Change and Water Initiative of the International Development Research Centre, Ottawa. http://www.dw.angonet.org/content/poverty-environmental-vulnerability-angola\%E2\%80\%99s-growing$\underline{\text { slums-2009-2012 }}$

Development Workshop (2012), Angolan Urban Land Policies, Strengthening Citizenship through Upgrading Informal Settlements, World Bank Land Conference, 26-28 April 2012 Washington, DC. http://www.landandpoverty.com/agenda/pdfs/ppt/cain_powerpoint.pdf

Development Workshop (2018) "Base-Line Study Angola Land Management Project" http://www.dw.angonet.org/content/land-rights-settlements

Ducados, H. (2002) "Luanda Peri-Urban Gender \& Household Profile" http://www.dw.angonet.org/content/luanda-peri-urban-household-gender-profile-2001-2002.

Global Land Tool Network (2012) Handling Land: Innovative tools for land governance and secure tenure. Nairobi: UN-Habitat. Available online at www.unhabitat.org.

MOSAIKO (2017) O Direito à Terra, http://www.dw.angonet.org/sites/default/files/direito a terra _mosaiko_inform19.pdf

Nielsen R. (2008) “Women's Land Rights in Post-Conflict Angola”, Reports on Foreign Aid \& Development, Number 125. http://www.dw.angonet.org/content/womens-land-rights-post-conflict-angola-0

Pacheco, F. (2002) “The issue of land and agriculture in Angola.” Rome: Food and Agriculture Organization of the United Nations.

Royston L (2013) In the Meantime ... Moving towards secure tenure by recognising local practice. In: Napier M et al. (2013) Trading Places: Accessing land in African Cities. Somerset West: African Minds. 
UN-Habitat (2003) Handbook on Best Practices, Security of Tenure and Access to Land: Implementation of the Habitat Agenda. Nairobi: Un-Habitat. Available online at http:// tinyurl.com/cd4565q.

Uniao Europea (2016), Manual para a Delimitação Participativa de Terras Comunitárias em Angola, http://www.dw.angonet.org/sites/default/files/manual_dpterras_quartarevisao_2.pdf

Urban LandMark (2013) Incrementally Securing Tenure: An approach for informal settlement upgrading in Southern Africa. Pretoria: Urban LandMark. Available online at www.urbanlandmark.org.za.

USAID (2007) "Strategy For Linking Improvements in Land Tenure With Enterprise Development in the Huambo Region", http://www.dw.angonet.org/forumitem/strategy-linking-improvements-land-thenureenterprise-development-huambo-region 